\title{
Influence of Pertussis Toxin Pretreatment on the Development of L-NAME-Induced Hypertension
}

\author{
J. ZICHA ${ }^{1,2}$, J. KUNES̆ ${ }^{1,2}$, S. VRANKOVÁ ${ }^{3}$, L. JENDEKOVÁ ${ }^{3}$, Z. DOBEŠOVÁ $^{1,2}$, \\ M. PINTÉROVÁ ${ }^{1,2}$, O. PECHÁŇOVÁ ${ }^{1,3}$ \\ ${ }^{1}$ Institute of Physiology, Academy of Sciences of the Czech Republic, Prague, ${ }^{2}$ Centre of \\ Cardiovascular Research, Prague, Czech Republic, and ${ }^{3}$ Institute of Normal and Pathological \\ Physiology, Slovak Academy of Sciences, Bratislava, Slovak Republic
}

Received September 14, 2009

Accepted October 5, 2009

\begin{abstract}
Summary
High blood pressure (BP) of L-NAME hypertensive rats is maintained not only by the absence of nitric oxide (NO)dependent vasodilatation but also by the enhancement of both sympathetic and angiotensin II-dependent vasoconstriction. The aim of the present study was to evaluate the role of inhibitory G $\left(G_{i}\right)$ proteins, which are involved in tonic sympathetic vasoconstriction, in the pathogenesis of NO-deficient hypertension. We therefore studied BP response to chronic L-NAME administration (60 mg/kg/day for 4 weeks) in rats in which the in vivo inactivation of $\mathrm{G}_{i}$ proteins was induced by injection of pertussis toxin (PTX, $10 \mu \mathrm{g} / \mathrm{kg}$ i.v.). The impairment of sympathetic vasoconstriction due to PTX-induced $G_{i}$ protein inactivation prevents the full development of NO-deficient hypertension because BP of PTX-treated rats subjected to chronic L-NAME administration did not reach hypertensive values. Nevertheless, chronic NO synthase inhibition per se is capable to increase moderately BP even in PTX-treated rats. Our data suggest that the sympathetic vasoconstriction is essential for the development of established NO-deficient hypertension.
\end{abstract}

\section{Key words}

Sympathetic nervous system • Nitric oxide • Inhibitory $G$ proteins

- Blood pressure

\section{Corresponding author}

Josef Zicha, MD, DSc, Institute of Physiology AS CR, Vídeňská 1083, 14220 Prague 4, Czech Republic. FAX: +420 241062488.

E-mail: zicha@biomed.cas.cz
Although the inhibition of NO synthesis is the primary stimulus for the development of hypertension elicited by chronic administration of NO synthase inhibitor L-NAME, the enhanced activity of sympathetic nervous system is a necessary prerequisite for establishing the chronic phase of this form of experimental hypertension (Sander and Victor 1999). Our previous study (Pecháňová et al. 2004) documented the enhanced pressor contribution of both renin-angiotensin and sympathetic nervous systems to blood pressure (BP) maintenance in L-NAME hypertensive rats. Several earlier papers (Pecháňová et al. 1997, Bernátová et al. 1999) reported the prevention of the development of NOdeficient hypertension in rats subjected to simultaneous administration of captopril or other angiotensin converting enzyme inhibitors. It should, however, be noted that the main mechanism through which chronic captopril treatment diminished BP rise in L-NAMEtreated rats, is the attenuation of sympathetic vasoconstriction (Zicha et al. 2006).

To examine the role of sympathetic nervous system in the development of NO-deficient hypertension, we decided to impair the efficiency of sympathetic vasoconstriction by the in vivo pretreatment of rats with pertussis toxin (PTX) which inactivates inhibitory $G\left(G_{i}\right)$ proteins participating in $\alpha$-adrenergic contraction ( $\mathrm{Li}$ and Triggle 1993). The inactivation of $G_{i}$ proteins leads to augmented formation of cyclic AMP and consequent vasodilatation due to attenuated calcium influx (Orlov et al. 1996). The up-regulation of $\mathrm{G}_{\mathrm{i}}$ protein pathway is 
involved in the pathogenetic mechanisms of various forms of experimental hypertension (Anand-Srivastava 1997, Bassil and Anand-Srivastava 2006) including genetic (Marcil et al. 1997, Li and Anand-Srivastava 2002) and NO-deficient hypertension (Di Fusco and Anand-Srivastava 1997, 2000). PTX pretreatment of Wistar rats causes a major attenuation of norepinephrineinduced contraction of isolated arteries in vitro (Líšková et al. 2007a) and a substantial reduction of pressor contribution of sympathetic nervous system to BP maintenance which is only partially compensated by considerable augmentation of angiotensin II-dependent vasoconstriction (Pintérová et al. 2007). The aim of the present study was to evaluate $\mathrm{BP}$ response to chronic L-NAME administration under the conditions of impaired sympathetic nervous system activity and augmented renin-angiotensin system activity.

Twenty-four 12-week-old male Wistar rats (bred in the Institute of Physiology AS CR, Prague) were used in this study. All animals were kept under standard laboratory conditions (12 h light, $12 \mathrm{~h}$ darkness, $23 \pm 1{ }^{\circ} \mathrm{C}$, pelleted ST-1 diet, drinking ad libitum). All procedures and experimental protocols were approved by the Animal Care Ethical Committee of the Institute of Physiology AS $\mathrm{CR}$ and conformed to the European Convention on Animal Protection and Guidelines on Research Animal Use. Twelve rats were injected $10 \mu \mathrm{g}$ PTX $/ \mathrm{kg}$ b.w. into jugular vein under ether anesthesia. Half of PTX-treated rats and six untreated animals were subjected to chronic L-NAME administration ( $60 \mathrm{mg} / \mathrm{kg} /$ day) for three weeks, whereas equal number of PTX-treated and untreated rats drank tap water only. At the end of the experiment blood pressure was measured by a direct puncture of carotid artery under light ether anesthesia. Heart, aorta, kidney, liver, cerebellum and brain cortex were dissected and homogenized. Total NO synthase (NOS) activity and neuronal NOS (nNOS) activity (susceptible to the inhibition by $10^{-4} \mathrm{M}$ S-methyl-L-thiocitrulline, SMTC) were determined in crude homogenates of heart, aorta, kidney and cerebellum by measuring L- $\left[{ }^{3} \mathrm{H}\right]$ citrulline from L- $\left[{ }^{3} \mathrm{H}\right]$ arginine (Amersham, UK) as previously described by Bredt and Snyder (1990) with minor modifications (Pecháňová et al. 1997).

The concentration of conjugated dienes was measured in lipid extracts of heart, kidney and brain cortex homogenates by the method of Kogure et al. (1982). After chloroform evaporation under the inert atmosphere and addition of cyclohexane, conjugated diene concentrations were determined

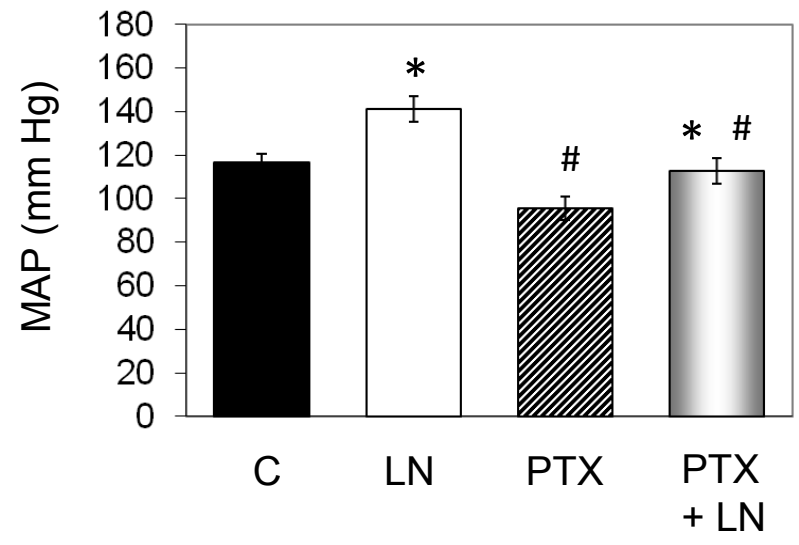

Fig. 1. Mean arterial pressure in L-NAME-treated rats and their controls which were either left intact or pretreated with pertussis toxin (PTX). Data are means \pm S.E.M. $(n=6)$. Asterisks indicate significant $(p<0.001)$ effects of chronic L-NAME treatment, whereas crosses indicate significant $(p<0.001)$ effects of PTX treatment.

spectrophotometrically ( $\lambda=233 \mathrm{~nm}$, GBC 911A, BioRad Laboratories). Reduced glutathione (GSH) levels were measured in heart, kidney, liver and brain cortex by the method of Ellman (1959). Samples of tissue were homogenized in 0.5 vol of ice-cold $5 \%$ sulphosalicylic acid and, after centrifugation at $12.000 \mathrm{x}$ for $15 \mathrm{~min}, \mathrm{GSH}$ concentration was determined spectrophotometrically in the acid-soluble fractions $(\lambda=412 \mathrm{~nm}, \mathrm{GBC} 911 \mathrm{~A}$, BioRad Laboratories). Results are expressed as means \pm S.E.M. One-way ANOVA and Bonferroni test were used for the statistical analysis. $\mathrm{P}<0.05$ value was considered as statistically significant.

Three weeks of L-NAME treatment increased blood pressure by about $25 \mathrm{~mm} \mathrm{Hg}$. PTX pretreatment prevented the development of L-NAME-induced hypertension because BP of these animals did not surpass $\mathrm{BP}$ values seen in intact controls. However, we can still see a significant L-NAME-induced BP rise by $17 \mathrm{~mm} \mathrm{Hg}$ if we compare these rats with PTX-pretreated controls (Fig. 1). The inactivation of inhibitory G protein by PTX administration did not influence total NOS activity in either organ examined (heart, aorta or kidney) (data not shown). Figure 2 shows that neither total NOS activity nor its SMTC-sensitive fraction (corresponding to nNOS activity) in the cerebellum were affected by PTX pretreatment. It also demonstrates that the reduction of total NOS activity in the cerebellum of L-NAME-treated rats was entirely at the expense of nNOS inhibition (Fig. 2). The concentration of conjugated dienes was increased in the brain cortex (Fig. 3) but not in the heart or kidney of L-NAME hypertensive rats (data not 

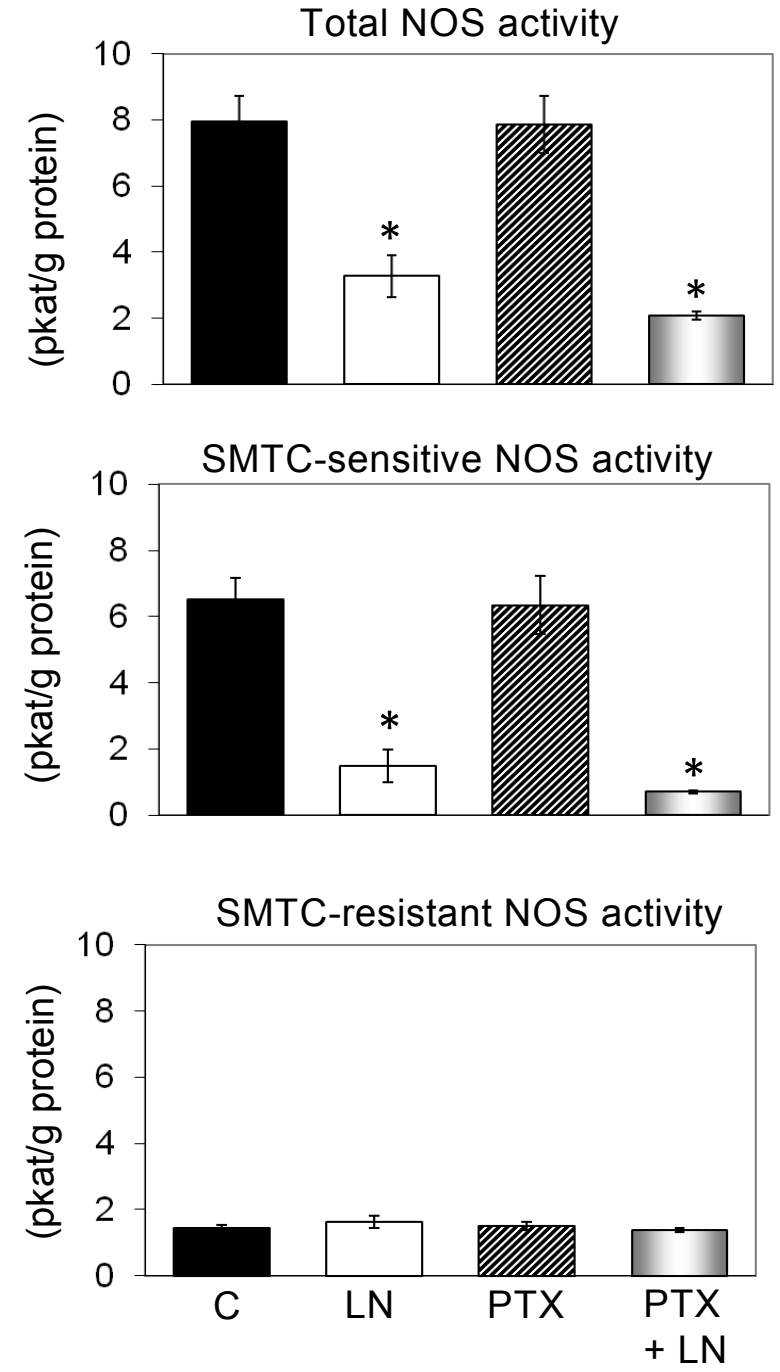

Fig. 2. Total NOS activity (upper panel), NOS activity susceptible (middle panel) or resistant (lower panel) to the inhibition by $10^{-4} \mathrm{M}$ SMTC in cerebellum of L-NAME-treated rats and their controls which were either left intact or pretreated with pertussis toxin (PTX). Data are means \pm S.E.M. $(n=6)$. Asterisks indicate significant $(p<0.001)$ effects of chronic L-NAME treatment.

shown). The same tendency was also observed in PTXpretreated rats. Thiol levels in brain cortex were not affected by chronic L-NAME treatment of either intact or PTX-pretreated rats (Fig. 3). No important changes of thiol levels were seen in the heart, kidney and liver of NO-deficient animals (data not shown).

Our present results confirm the importance of sympathetic nervous system for the pathogenesis of NOdeficient hypertension as it was suggested by Sander and Victor (1999). Furthermore, these data indicate that our previous observation (Zicha et al. 2006) on the antihypertensive action of captopril in L-NAME-treated rats through the attenuation of sympathetic vasoconstriction was correct. The fact that blood pressure
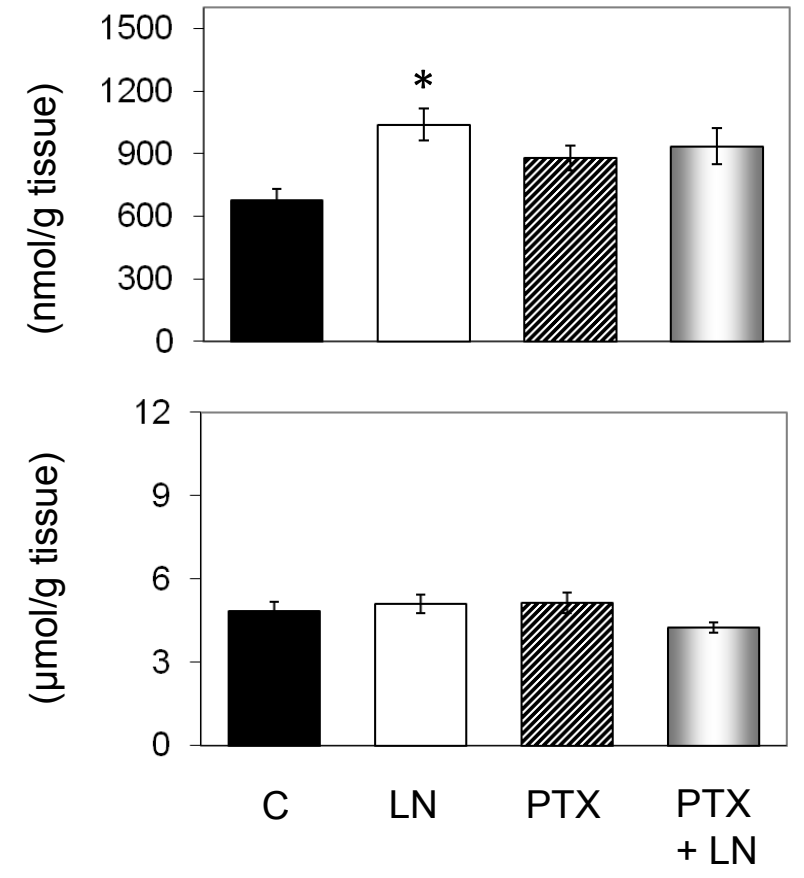

Fig. 3. Conjugated diene concentrations (upper panel) and thiol levels (lower panel) in brain cortex of L-NAME-treated rats and their controls which were either left intact or pretreated with pertussis toxin (PTX). Data are means \pm S.E.M. $(n=6)$. Asterisks indicate significant $(p<0.05)$ effects of chronic L-NAME treatment.

of PTX-pretreated rats rose following L-NAME administration, but did not reach hypertensive values, resembles our recent findings in PTX-treated spontaneously hypertensive rats in which blood pressure decreased to the level of normotensive controls, but it was still elevated compared to PTX-treated Wistar-Kyoto rats (Lišková et al. 2007b). It is important to note that pressor action of angiotensin II, which is several fold augmented in PTX-treated rats, is insufficient perse to maintain hypertensive BP values in either NO-deficient (this study) or genetic hypertension (Pintérová et al. 2009).

Since optimal nitric oxide/ROS balance in the brain seems to be an important parameter in the prevention of hypertension, concentrations of both thiols and $\mathrm{CD}$ - marker of membrane oxidative damage - were determined. While thiol levels in the brain cortex were affected neither after the L-NAME nor after PTX treatment, concentration of $\mathrm{CD}$ was increased after the L-NAME treatment significantly. The same tendency was observed in PTX-pretreated rats. The brain is especially susceptible to the oxidative damage because it is not particularly endowed with an antioxidant defense. It has only low catalase activity and moderate levels of the antioxidant enzymes like superoxide dismutase and 
glutathione peroxidase. The high levels of iron and ascorbate in the brain may participate significantly at the catalysis of lipid peroxidation (for review see Lau et al. 2005). Since L-NAME administration may lead to downregulation of superoxide dismutase (Husain, 2003) and attenuation of glutathione peroxidase activity in the brain (Barthwal et al. 2000), it is quite plausible that decreased antioxidant defense is accounted for increased $C D$ concentration in the brain cortex. Similarly, increased CD concentration and up-regulation of redox sensitive factor $\mathrm{NF}-\kappa \mathrm{B}$ were documented in different brain regions after long-term L-NAME treatment (Pechánová et al. 2006).

In conclusion, the presence of functional sympathetic nervous system is critical for the full development of NO-deficient hypertension and its decisive role cannot be replaced by enhanced activity of renin-angiotensin system. Further studies should be focused on the moderate BP difference persisting in NOdeficient rats treated with either pertussis toxin or captopril when compared to similarly treated controls.

\section{Conflict of Interest}

There is no conflict of interest.

\section{Acknowledgements}

This study was partially supported by research grants of GA CR 305/08/0139, AV0Z 50110509, and 1M0510 (Ministry of Education of the Czech Republic). The excellent technical assistance of Mrs. Marie Schützová and Mrs. Iva Nahodilová is greatly appreciated.

\section{References}

ANAND-SRIVASTAVA MB: Atrial natriuretic peptide-C receptor and membrane signalling in hypertension. J Hypertens 15: 815-826, 1997.

BARTHWAL MK, SRIVASTAVA N, NAG D, SETH PK, SRIMAL RC, DIKSHIT M: Antioxidant levels in the rat brain after nitric oxide synthase inhibition: a preliminary report. Redox Rep 5: 75-80, 2000.

BASSIL M, ANAND-SRIVASTAVA MB: Nitric oxide modulates Gi-protein expression and adenylyl cyclase signaling in vascular smooth muscle cells. Free Radic Biol Med 41: 1162-1173, 2006.

BERNÁTOVÁ I, PECHÁŇOVÁ O, ŠIMKO F: Effect of captopril in L-NAME-induced hypertension on the rat myocardium, aorta, brain and kidney. Exp Physiol 84: 1095-1105, 1999.

BREDT DS, SNYDER SH: Isolation of nitric oxide synthetase, a calmodulin-requiring enzyme. Proc Natl Acad Sci USA 87: 682-685, 1990.

Di FUSCO F, ANAND-SRIVASTAVA MB: Nitric oxide synthase inhibition by $\mathrm{N}^{\omega}$-nitro-L-arginine methyl ester modulates G-protein expression and adenylyl cyclase activity in rat heart. Am J Hypertens 10: 71-75, 1997.

DI FUSCO F, ANAND-SRIVASTAVA MB: Enhanced expression of Gi proteins in non-hypertrophic hearts from rats with hypertension-induced by L-NAME treatment. J Hypertens 18: 1081-1090, 2000.

ELLMAN GL: Tissue sulhydryl groups. Arch Biochem Biophys 82: 70-77, 1959.

HUSAIN K: Interaction of exercise training and chronic NOS inhibition on blood pressure, heart rate, NO and antioxidants in plasma of rats. Pathophysiology 10: 47-56, 2003.

KOGURE K, WATSON BD, BUSTO R, ABE K: Potentiation of lipid peroxides by ischemia in rat brain. Neurochem Res 7: 437-454, 1982.

LAU FC, SHUKITT-HALE B, JOSEPH JA: The beneficial effects of fruit polyphenols on brain aging. Neurobiol Aging 26: 128-132, 2005.

LI Y, ANAND-SRIVASTAVA MB: Inactivation of enhanced expression of $\mathrm{G}_{\mathrm{i}}$-proteins by pertussis toxin attenuates the development of high pressure in spontaneously hypertensive rats. Circ Res 91: 247-254, 2002.

LI X-F, TRIGGLE CR: Effect of pertussis and cholera toxins on alpha-adrenoceptor function in rat tail artery: differences in hypertention. Can J Physiol Pharmacol 71: 791-799, 1993.

LÍŠKOVÁ S, ZICHA J, KUNEŠ J: Nifedipine-sensitive vascular reactivity of femoral arteries in WKY: the effect of pertussis toxin pretreatment and endothelium removal. Physiol Res 56: 663-666, 2007a.

LÍŠKOVÁ S, ZICHA J, KUNEŠ J: Effect of pertussis toxin on vascular reactivity of femoral arteries in WKY and SHR. In: Nitric Oxide Signaling Pathways, O PECHÁŇOVÁ (ed), Advent-Orion, Bratislava, 2007b, pp 89-94.

MARCIL J, THIBAULT C, ANAND-SRIVASTAVA MB: Enhanced expression of Gi-protein precedes the development of blood pressure in spontaneously hypertensive rats. J Mol Cell Cardiol 29: 1009-1020, 1997. 
ORLOV SN, TREMBLAY J, HAMET P: cAMP signaling inhibits dihydropyridine-sensitive $\mathrm{Ca}^{2+}$ influx in vascular smooth muscle cells. Hypertension 27: 774-780, 1996.

PECHÁŇOVÁ O, BERNÁTOVÁ I, PELOUCH V, ŠIMKO F: Protein remodeling in the heart of NO-deficient hypertension: the effect of captopril. J Mol Cell Cardiol 29: 3365-3374, 1997.

PECHÁŇOVÁ O, DOBEŠOVÁ Z, ČEJKA J, KUNEŠ J, ZICHA J: Vasoactive systems in L-NAME hypertension: the role of inducible NO synthase. J Hypertens 22: 167-173, 2004.

PECHÁŇOVÁ O, JENDEKOVÁ L, KOJŠOVÁ S, JAGLA F: Possible role of nitric oxide in the locomotor activity of hypertensive rats. Behav Brain Res 174: 160-166, 2006.

PINTÉROVÁ M, KUNEŠ J, DOBEŠOVÁ Z, ZICHA J: In vivo effects of pertussis toxin on adrenergic vasoconstriction. In: Nitric Oxide Signaling Pathways, O PECHÁŇOVÁ (ed), Advent-Orion, Bratislava, 2007, pp 76-82.

PINTÉROVÁ M, LÍŠKOVÁ S, DOBEŠOVÁ Z, BEHULIAK M, KUNEŠ J, ZICHA J: Impaired control of L-type voltage-dependent calcium channels in experimental hypertension. Physiol Res 58 (Suppl 2): in press, 2009.

SANDER M, VICTOR RG: Neural mechanisms in nitric-oxide-deficient hypertension. Curr Opin Nephrol Hypertens 8: 61-73, 1999.

ZICHA J, DOBEŠOVÁ Z, KUNEŠ J: Antihypertensive mechanisms of chronic captopril or N-acetylcysteine treatment in L-NAME hypertensive rats. Hypertens Res 29: 1021-1027, 2006. 